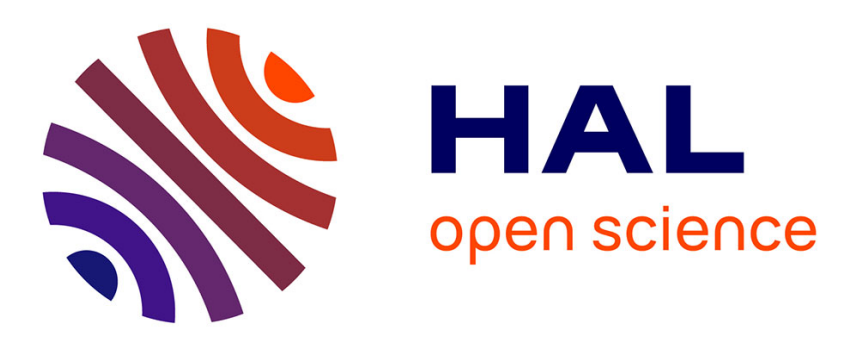

\title{
Crystal structure of a new pentadentate symmetrical: di[4-(phenylimino)pentan-2-one] ether. Structural and electrochemical studies of its CoII, NiII, CuII and CdII complexes
}

Ilhem Kaabi, Tahar Douadi, Djahida Haffar, Salah Chafaa, Magali Allain, Mustayeen A Khan, Gilles M Bouet

\section{To cite this version:}

Ilhem Kaabi, Tahar Douadi, Djahida Haffar, Salah Chafaa, Magali Allain, et al.. Crystal structure of a new pentadentate symmetrical: di[4-(phenylimino)pentan-2-one] ether. Structural and electrochemical studies of its CoII, NiII, CuII and CdII complexes. Transition Metal Chemistry, 2007, 32, pp.666 673. 10.1007/s11243-007-0229-z . hal-03232188

\section{HAL Id: hal-03232188 \\ https://univ-angers.hal.science/hal-03232188}

Submitted on 31 May 2021

HAL is a multi-disciplinary open access archive for the deposit and dissemination of scientific research documents, whether they are published or not. The documents may come from teaching and research institutions in France or abroad, or from public or private research centers.
L'archive ouverte pluridisciplinaire HAL, est destinée au dépôt et à la diffusion de documents scientifiques de niveau recherche, publiés ou non, émanant des établissements d'enseignement et de recherche français ou étrangers, des laboratoires publics ou privés. 


\title{
Crystal structure of a new pentadentate symmetrical: di[4-(phenylimino)pentan-2- one] ether. Structural and electrochemical studies of its $\mathrm{Co}^{\mathrm{II}}, \mathrm{Ni}^{\mathrm{II}}, \mathrm{Cu}^{\mathrm{II}}$ and $\mathrm{Cd}^{\mathrm{II}}$ complexes
}

\author{
Ilhem Kaabi, Tahar Douadi, Djahida Haffar and Salah Chafaa \\ Laboratoire d'Électrochimie des Matériaux Moléculaires et Complexes, Département de Génie des Procédés, Faculté \\ des Sciences de l'Ingénieur, Université Ferhat Abbas, Setif DZ-19000, Algeria \\ Magali Allain \\ Faculté des Sciences, CIMMA, UMR CNRS 6200, 2 Boulevard Lavoisier, F-49045 Angers Cedex France
}

Mustayeen A. Khan and Gilles M. Bouet*

Faculté de Pharmacie, SONAS, EA 921, Université d'Angers, 16 Boulevard Daviers, F-49045 Angers Cedex 01 France

Received 08 February 2007; accepted 05 March 2007

\begin{abstract}
The crystal structure of a new symmetrical pentadentate $\mathrm{N}_{2} \mathrm{O}_{3}$ Schiff base: di[4-(phenylimino)pentan-2-one] ether $\left(\mathrm{H}_{2} \mathrm{~L}\right)$ is described. In the solid state, the ligand appears as a keto-imine tautomer, while in DMSO solution, the eneamine form is observed. This ligand coordinates cobalt(II), nickel(II), copper(II) and cadmium(II). The structures of these new complexes are described using infrared and electronic spectroscopy, ${ }^{1} \mathrm{H}-\mathrm{n} . \mathrm{m} . \mathrm{r}$. and d.s.c. The cyclic voltammograms of the ligand and the complexes in DMF are discussed.
\end{abstract}

\section{Introduction}

Since the first report of their metal complexes, Schiff bases have been widely used as ligands in many complex species [1]. Among these bases, very few are obtained with acetylacetone and show in addition an ether function in their chemical structure.

Cheng et al. reported the synthesis of three ligands of the type bis[4-(2-pyridylmethyleneamino)phenyl] ether and their complexes with $\mathrm{Ag}^{+}, \mathrm{Co}^{2+}$ and $\mathrm{Ni}^{2+}$ [2]. In 2004, Casellato et al. described the synthesis of complexes from Schiff bases, starting from various multidentate ligands [3]. Recently, Mentes et al. described molybdenum tetracarbonyl complexes with polyether-containing Schiff base ligands [4]. More recently, the crystal structure of a symmetrical $\mathrm{N}_{4} \mathrm{O}$ Schiff base was published by Vallina et al. [5].

The synthesis of Schiff bases deriving from acetylacetone was first described by Combes [6] and their metal complexes have been studied by Morgan and Main-Smith [7] and Schwarzenbach et al. [8]. These bases and their metal complexes may be involved as catalysts for many reactions [9-15].

Some papers dealt with $\mathrm{N}_{2} \mathrm{O}_{3}$ pentadentate Schiff bases [16-18]. Among them very few reported the behaviour of Schiff bases bearing an ether functional group $[16,17]$. In our continuous work about symmet-

\footnotetext{
* Author for correspondence: E-mail: gilles.bouet@univ-angers.fr
}

rical Schiff bases, with various links between the symmetrical moieties $[19,20]$, we describe here a new series of complexes with a new symmetrical potent pentadentate base as ligand: di[4-(phenylimino)pentan2-one] ether in order to obtain some complex species useful to extract metal from environment. The crystal structure of the ligand is given; the structures of the complexes and their electrochemical properties are described.

\section{Experimental}

\section{Materials}

All materials and solvents were analytical grade and used without further purification. 4,4'-diaminodiphenyl ether and acetylacetone were purchased from SigmaAldrich, France. All metals were hydrated chlorides and were used as received.

\section{Preparation of the ligand}

The ligand was obtained by reacting $4,4^{\prime}$-diaminodiphenyl ether and acetylacetone in EtOH (1:2 molar ratio) according to Cai [15] and Reddy [21]. To a hot solution of 4,4'-diaminodiphenyl ether ( $1 \mathrm{mmol}, 0.4 \mathrm{~g}$, $5 \mathrm{ml}$ ) was added a solution of aceylacetone $(2 \mathrm{mmol}$, $0.6 \mathrm{~g}, 1.47 \mathrm{ml})$. The mixture was refluxed for $3 \mathrm{~h}$ and 
cooled. The yellow product was filtered, washed twice with $\mathrm{EtOH}(10 \mathrm{ml})$ and finally recrystallised from toluene and dried under vacuum. The single crystals for X-ray diffraction were obtained by slow evaporation from toluene.

\section{Syntheses of the complexes}

All the complexes were prepared using two synthetic pathways: one by mixing in EtOH equimolar amounts of ligand $(0.2 \mathrm{~g}, 4 \mathrm{ml})$ and hydrated chlorides $(10 \mathrm{ml})$ and the other using a one step operating mode by mixing 4,4'-diaminodiphenyl ether, acetylacetone and metal salt as it has been reported for similar compounds $[9,22]$. After standing under reflux conditions for $8 \mathrm{~h}$, the mixture was kept overnight at room temperature. When toluene $(30 \mathrm{ml})$ was added, the complex precipitated. It was removed by filtration, washed several times with hot EtOH and dried under vacuum. Their purity was verified using t.l.c.

\section{Measurements}

All elemental analysis were carried out at the "Service de Microanalyse du C.N.R.S., I.C.S.N.", Gif sur Yvette (France). The melting points were determined with a Kofler bank and are uncorrected. The i.r. spectra were recorded with a Perkin-Elmer 1000 series FT-IR spectrophotometer, using $\mathrm{KBr}$ disks. The u.v.-vis spectra were obtained in DMF with a UNICAM UV300 spectrophotometer. The ${ }^{1} \mathrm{H}$ n.m.r. spectra were recorded on a Jeol GSX WB spectrometer at $270 \mathrm{MHz}$ in DMSO-D 6 , the chemical shifts are given in p.p.m., using TMS as internal reference. D.s.c. diagrams were recorded in the $25-400{ }^{\circ} \mathrm{C}$ range with a Mettler DSC $822^{\mathrm{e}}$ unit, with the help of Mettler Toledo STAR $^{\text {e }}$ SW 8.10 System software (Laboratoire de Physique, Faculté de Pharmacie, Angers); the heating rate was $10^{\circ} \mathrm{C}$ per minute; all measurements were made in $40 \mathrm{~mm}^{3}$ closed Al crucibles. Electrochemical measurements were recorded on a Radiometer VOLTALAB 32 (DEA 332 type): the working electrode was a $2 \mathrm{~mm}$ diameter $\mathrm{Pt}$ rotating disk and the auxiliary electrode a Pt wire. A saturated calomel electrode was used as the reference electrode and measurements were carried out at $25 \pm 0.2^{\circ} \mathrm{C}$. DMF was used as solvent and the ionic strength maintained at $0.1 \mathrm{~mol} \mathrm{l}^{-1}$, with $\mathrm{Bu}_{4} \mathrm{NPF}_{6}$ as supporting electrolyte. The concentrations of species were in the $2.5 .10^{-3}$ to $5.10^{-3} \mathrm{~mol} \mathrm{l}^{-1}$ range. The sweep speed was $100 \mathrm{mV} \mathrm{s}^{-1}$ unless otherwise indicated.

\section{Crystal data collection and processing}

Crystals of the ligand are monoclinic with space group $\mathrm{P} 22_{1 / \mathrm{c}}$. The crystal and instrumental parameters used in the unit-cell determination and data collection are summarised in Table 1. X-ray single-crystal diffraction data were collected at $293 \mathrm{~K}$ on a STOE-IPDS diffrac-
Table 1. Crystallographic data for the ligand

\begin{tabular}{ll}
\hline Formula & $\mathrm{C}_{22} \mathrm{H}_{2} \mathrm{~N}_{2} \mathrm{O}_{3}$ \\
Formula weight & 364.43 \\
Crystal system & Monoclinic \\
Space group & $\mathrm{P}{ }_{1} / \mathrm{c}$ \\
$a(\AA)$ & $14.7610(10)$ \\
$b(\AA)$ & $6.4467(4)$ \\
$c(\AA)$ & $23.986(2)$ \\
$\alpha\left({ }^{\circ}\right)$ & 90 \\
$\beta\left({ }^{\circ}\right)$ & $96.092(9)$ \\
$\gamma\left({ }^{\circ}\right)$ & 90 \\
$V\left(\AA^{3}\right)$ & $2269.6(3)$ \\
$Z$ & 4 \\
Color & Yellow \\
$D_{\text {calc }}\left(\mathrm{gcm}^{-3}\right)$ & 1.067 \\
$F(000)$ & 776 \\
$\mu\left(\mathrm{mm}^{-1}\right)$ & 0.071 \\
hkl limits & $-18 \leq \mathrm{h} \leq 18,-7 \leq \mathrm{k} \leq 7$, \\
& $-28 \leq 1 \leq 29$ \\
$\theta_{\text {min }}, \theta_{\text {max }}\left({ }^{\circ}\right)$ & 2.26 \\
Number of data with $I>2 \sigma(I)$ & $2294 \mathrm{~F}_{\mathrm{o}}$ \\
Weighting scheme & $w=1 /\left[\sigma^{2}\left(\mathrm{Fo}^{2}\right)+(0.1714 \mathrm{P})^{2}\right]$ \\
& with $\mathrm{P}=\left(\mathrm{Fo}^{2}+2 \mathrm{Fc}^{2}\right) / 3$ \\
Number of variables & 250 \\
$R 1$ & 0.1122 \\
w $R 2$ & 0.2969 \\
\hline
\end{tabular}

tometer, equipped with a graphite monochromator utilising $\operatorname{MoK}_{\alpha}$ radiation $(\lambda=0.71073 \AA$ ) (CIMMA, UMR CNRS 6200, Angers). The structure was solved by direct methods and the refinement was performed on $\mathrm{F}^{2}$ by full matrix least-squares techniques using SHELX-97 [23] package. All non-H atoms were refined anisotropically and the $\mathrm{H}$ atoms were included in the calculation without refinement. Absorption was corrected by Gaussian technique.

\section{Results and discussion}

\section{Crystal structure of the ligand}

The main crystal parameters are reported in Table 1. The bond distances and their angles are given in Tables 2 and 3, respectively.

An ORTEP view of the molecule with the numbering scheme is given in Figure 2. Without taking into account the methyl and the methylene groups, all angles are equal to $120^{\circ}$ (with minor variations) showing $\mathrm{sp}^{2}$ hybridisation of the corresponding carbon atoms. The lengths of the $\mathrm{C}(02)-\mathrm{O}(02)$ and $\mathrm{C}(21)-\mathrm{O}(03)$ bonds $(1.24 \AA$ A $)$ are consistent with a keto double bond as described by Nathan et al. for similar compounds [24]. In the azomethine moiety, the $\mathrm{C}(04)-\mathrm{N}(01)$ and $\mathrm{C}(18)-\mathrm{N}(02)$ bonds are longer than the keto double bonds (1.34 and $1.32 \AA$ respectively) and shorter than the single bonds $\mathrm{C}(06)-\mathrm{N}(01)$ and $\mathrm{C}(15)-\mathrm{N}(02)(1.42$ and $1.44 \AA$ ) [24]. The two $\mathrm{C}=\mathrm{N}$ bonds are in $E$ configuration. The ether linkage shows a $118.7(3)^{\circ}$ angle, instead of $109.5^{\circ}$ in the case of a typical $\mathrm{sp}^{3}$ hybridisation. This means that the repulsion of the $\pi$ electronic 
Table 2. Bond lengths ( $(\AA)$

\begin{tabular}{llll}
\hline Atoms & Bond length $(\AA)$ & Atoms & Bond length $(\AA)$ \\
\hline $\mathrm{C}(01)-\mathrm{C}(02)$ & $1.512(6)$ & $\mathrm{C}(12)-\mathrm{C}(17)$ & $1.379(7)$ \\
$\mathrm{C}(02)-\mathrm{O}(02)$ & $1.244(5)$ & $\mathrm{C}(12)-\mathrm{C}(13)$ & $1.381(7)$ \\
$\mathrm{C}(02)-\mathrm{C}(03)$ & $\mathrm{C}(12)-\mathrm{O}(01)$ & $1.400(5)$ \\
$\mathrm{C}(03)-\mathrm{C}(04)$ & $\mathrm{C}(13)-\mathrm{C}(14)$ & $1.366(6)$ \\
$\mathrm{C}(04)-\mathrm{N}(01)$ & $1.416(6)$ & $\mathrm{C}(14)-\mathrm{C}(15)$ & $1.386(6)$ \\
$\mathrm{C}(04)-\mathrm{C}(05)$ & $1.380(6)$ & $\mathrm{C}(15)-\mathrm{C}(16)$ & $1.380(6)$ \\
$\mathrm{C}(06)-\mathrm{C}(07)$ & $1.344(5)$ & $\mathrm{C}(15)-\mathrm{N}(02)$ & $1.440(5)$ \\
$\mathrm{C}(06)-\mathrm{C}(11)$ & $1.488(6)$ & $\mathrm{C}(16)-\mathrm{C}(17)$ & $1.388(6)$ \\
$\mathrm{C}(06)-\mathrm{N}(01)$ & $1.377(6)$ & $\mathrm{C}(18)-\mathrm{N}(02)$ & $1.322(5)$ \\
$\mathrm{C}(07)-\mathrm{C}(08)$ & $1.424(5)$ & $\mathrm{C}(18)-\mathrm{C}(20)$ & $1.376(6)$ \\
$\mathrm{C}(08)-\mathrm{C}(09)$ & $1.360(6)$ & $\mathrm{C}(18)-\mathrm{C}(19)$ & $1.508(6)$ \\
$\mathrm{C}(09)-\mathrm{C}(10)$ & $1.377(6)$ & $\mathrm{C}(20)-\mathrm{C}(21)$ & $1.411(6)$ \\
$\mathrm{C}(09)-\mathrm{O}(01)$ & $1.372(6)$ & $\mathrm{C}(21)-\mathrm{O}(03)$ & $1.243(5)$ \\
$\mathrm{C}(10)-\mathrm{C}(11)$ & $1.387(5)$ & $\mathrm{C}(21)-\mathrm{C}(22)$ & $1.494(6)$ \\
\hline
\end{tabular}

Table 3. Bond angles $\left({ }^{\circ}\right)$

\begin{tabular}{llll}
\hline Atoms & Angle $\left(^{\circ}\right)$ & Atoms & Angle $\left(^{\circ}\right)$ \\
\hline $\mathrm{O}(02)-\mathrm{C}(02)-\mathrm{C}(03)$ & $123.3(4)$ & $\mathrm{C}(13)-\mathrm{C}(12)-\mathrm{O}(01)$ & $120.0(5)$ \\
$\mathrm{O}(02)-\mathrm{C}(02)-\mathrm{C}(01)$ & $118.8(4)$ & $\mathrm{C}(14)-\mathrm{C}(13)-\mathrm{C}(12)$ & $119.4(4)$ \\
$\mathrm{C}(03)-\mathrm{C}(02)-\mathrm{C}(01)$ & $\mathrm{C}(13)-\mathrm{C}(14)-\mathrm{C}(15)$ & $120.4(4)$ \\
$\mathrm{C}(04)-\mathrm{C}(03)-\mathrm{C}(02)$ & $\mathrm{C}(16)-\mathrm{C}(15)-\mathrm{C}(14)$ & $120.0(4)$ \\
$\mathrm{N}(01)-\mathrm{C}(04)-\mathrm{C}(03)$ & $117.9(4)$ & $\mathrm{C}(16)-\mathrm{C}(15)-\mathrm{N}(02)$ & $119.6(4)$ \\
$\mathrm{N}(01)-\mathrm{C}(04)-\mathrm{C}(05)$ & $124.6(4)$ & $\mathrm{C}(14)-\mathrm{C}(15)-\mathrm{N}(02)$ & $120.4(4)$ \\
$\mathrm{C}(03)-\mathrm{C}(04)-\mathrm{C}(05)$ & $120.0(4)$ & $\mathrm{C}(15)-\mathrm{C}(16)-\mathrm{C}(17)$ & $120.0(4)$ \\
$\mathrm{C}(07)-\mathrm{C}(06)-\mathrm{C}(11)$ & $\mathrm{C}(12)-\mathrm{C}(17)-\mathrm{C}(16)$ & $118.9(4)$ \\
$\mathrm{C}(07)-\mathrm{C}(06)-\mathrm{N}(01)$ & $\mathrm{N}(02)-\mathrm{C}(18)-\mathrm{C}(20)$ & $121.7(4)$ \\
$\mathrm{C}(11)-\mathrm{C}(06)-\mathrm{N}(01)$ & $\mathrm{N}(02)-\mathrm{C}(18)-\mathrm{C}(19)$ & $118.2(4)$ \\
$\mathrm{C}(08)-\mathrm{C}(07)-\mathrm{C}(06)$ & $\mathrm{C}(20)-\mathrm{C}(18)-\mathrm{C}(19)$ & $120.1(4)$ \\
$\mathrm{C}(07)-\mathrm{C}(08)-\mathrm{C}(09)$ & $\mathrm{C}(18)-\mathrm{C}(20)-\mathrm{C}(21)$ & $124.4(4)$ \\
$\mathrm{C}(10)-\mathrm{C}(09)-\mathrm{C}(08)$ & $\mathrm{O}(03)-\mathrm{C}(21)-\mathrm{C}(20)$ & $122.2(4)$ \\
$\mathrm{C}(10)-\mathrm{C}(09)-\mathrm{O}(01)$ & $\mathrm{O}(03)-\mathrm{C}(21)-\mathrm{C}(22)$ & $118.1(4)$ \\
$\mathrm{C}(08)-\mathrm{C}(09)-\mathrm{O}(01)$ & $119.6(4)$ & $\mathrm{C}(20)-\mathrm{C}(21)-\mathrm{C}(22)$ & $119.8(4)$ \\
$\mathrm{C}(09)-\mathrm{C}(10)-\mathrm{C}(11)$ & $119.3(3)$ & $\mathrm{C}(04)-\mathrm{N}(01)-\mathrm{C}(06)$ & $128.3(3)$ \\
$\mathrm{C}(06)-\mathrm{C}(11)-\mathrm{C}(10)$ & $122.6(3)$ & $\mathrm{C}(18)-\mathrm{N}(02)-\mathrm{C}(15)$ & $125.4(3)$ \\
$\mathrm{C}(17)-\mathrm{C}(12)-\mathrm{C}(13)$ & $118.0(3)$ & $\mathrm{C}(09)-\mathrm{O}(01)-\mathrm{C}(12)$ & $118.7(3)$ \\
$\mathrm{C}(17)-\mathrm{C}(12)-\mathrm{O}(01)$ & $120.3(4)$ & & \\
\hline
\end{tabular}

Table 4. Analytical data

\begin{tabular}{lllclll}
\hline Compound & Color & Yield $(\%)$ & M.p. $\left({ }^{\circ} \mathrm{C}\right)$ & \multicolumn{3}{c}{ Elemental analysis found $($ Calcd.) $(\%)$} \\
& & & & C & H & N \\
\hline$\left[\left(\mathrm{CoCl}_{2}\right)_{2}\left(\mathrm{H}_{2} \mathrm{~L}\right)\right]$ & Tan & 51 & $>260$ & $43.6(42.3)$ & $3.7(3.9)$ & $8.2(4.5)$ \\
{$\left[\left(\mathrm{NiCl}_{2}\right)_{2}\left(\mathrm{H}_{2} \mathrm{~L}\right)\right] \cdot 2 \mathrm{H}_{2} \mathrm{O}$} & Yellow & 60 & $>260$ & $42.2(42.3)$ & $5.5(3.9)$ & $5.1(4.5)$ \\
{$\left[\mathrm{CuCl}_{2}\left(\mathrm{H}_{2} \mathrm{~L}\right)\right]$} & Brown & 46 & 176 & $53.3(52.9)$ & $4.5(4.8)$ & $6.8(6.8)$ \\
{$[\mathrm{CdL}] \cdot \mathrm{CdCl}_{2}$} & Yellow & 32 & $>260$ & $39.8(40.1)$ & $3.7(3.4)$ & $4.7(4.3)$ \\
\hline
\end{tabular}

cloud of the aromatic cycles is stronger than the repulsion of the two electronic pairs of the oxygen atom. In this case the lengths of the bonds correspond to single carbon-oxygen bond. In the single crystal, the ligand presents a keto-imine tautomer I (see Section 'Characterisation of the complexes').

There are four molecules in each cell. The packing along the $b$-axis (Figure 3 ) shows that the molecules lie in parallel directions but with alternate planes for the aromatic rings. In each molecule, the two aromatic rings lie in planes showing a $80.8^{\circ}$ angle as presented in Figure 4.

\section{Characterisation of the complexes}

The main analytical data are reported in Table 4 and the complexes should be formulated as $\left[\left(\mathrm{CoCl}_{2}\right)_{2}\left(\mathrm{H}_{2} \mathrm{~L}\right)\right],\left[\left(\mathrm{NiCl}_{2}\right)_{2}\left(\mathrm{H}_{2} \mathrm{~L}\right)\right] \cdot 2 \mathrm{H}_{2} \mathrm{O},\left[\mathrm{CuCl}_{2}\left(\mathrm{H}_{2} \mathrm{~L}\right)\right]$ 
<smiles>CC(=O)C/C(C)=N/c1ccc(Oc2ccc(/N=C(\C)CC(C)=O)cc2)cc1</smiles>

Fig. 1. Chemical structure of the ligand.

and $\left[\mathrm{CdH}_{2} \mathrm{~L}\right] \cdot \mathrm{CdCl}_{2}$ respectively. The complexes are somewhat unstable and all spectral determinations were done immediately after their synthesis.

Infrared spectra
nickel(II) and cadmium(II) complexes this band is shifted to higher wavenumbers showing that the keto oxygen atom is involved in the coordination. On the other hand, in the spectrum of the copper complex this band is very slightly shifted down and the keto oxygen atom is not a coordinating atom in this case. The $v(\mathrm{C}=\mathrm{N})$ vibration band is located at $1571 \mathrm{~cm}^{-1}$ in the spectrum of the ligand and it is not significantly displaced in the spectra of the complexes. However, this atom is a coordinating atom, but as the crystallographic data shows an electronic delocalisation along the molecule,

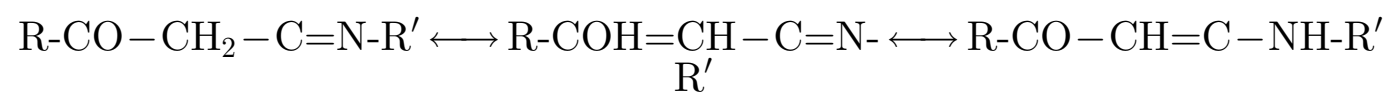

I

Keto - imine
II

$$
\text { Enol - imine }
$$

The Schiff bases undergo an equilibrium between three tautomers as indicated above. Structural studies about these ligands have indicated that they exist predominantly as the keto-amine tautomer III. This determination is first based upon i.r. spectra using bands in the $3400-3200 \mathrm{~cm}^{-1}$ region assigned to the $v(\mathrm{~N}-\mathrm{H})$ stretching vibration. However, infrared spectroscopy may not be a sufficient tool because it is difficult to distinguish between a $v(\mathrm{O}-\mathrm{H})$ of a coordinated enolimine tautomer II and a $v(\mathrm{~N}-\mathrm{H})$ of a coordinated keto-amine tautomer III [24, 25]. The second way is ${ }^{1}$ H-n.m.r by using the chemical shifts in the 8.4-12.6 p.p.m. range [26, 27].

The main spectral data is collected in Table 5. In the infrared spectrum of the ligand ( $\mathrm{KBr}$ disks), the vibration band relative to the ether linkage is located at $1247 \mathrm{~cm}^{-1}$ and it remains quite unchanged in the cases of the complexes. As expected this oxygen atom is not involved in the chelation in all cases and this base may act as a tetradentate $\mathrm{N}_{2} \mathrm{O}_{2}$ ligand. The keto stretching vibration band appears at $1610 \mathrm{~cm}^{-1}$ in the spectrum of the ligand and this wave number is typical of the presence of hydrogen bonding between this oxygen atom and the hydrogen atom from the imino functional group [25]. In the spectra of the cobalt(II),

\section{III}

Keto - amine the quite double bond characteristic nature is not modified after the complexation.

The aromatic ring vibrations are only slightly shifted by chelation. In the $3400-3200 \mathrm{~cm}^{-1}$ region, only the nickel complex exhibits a broad band around $3400 \mathrm{~cm}^{-1}$, corresponding the $\mathrm{O}-\mathrm{H}$ stretching vibration band of water molecules. In all other spectra, the shape

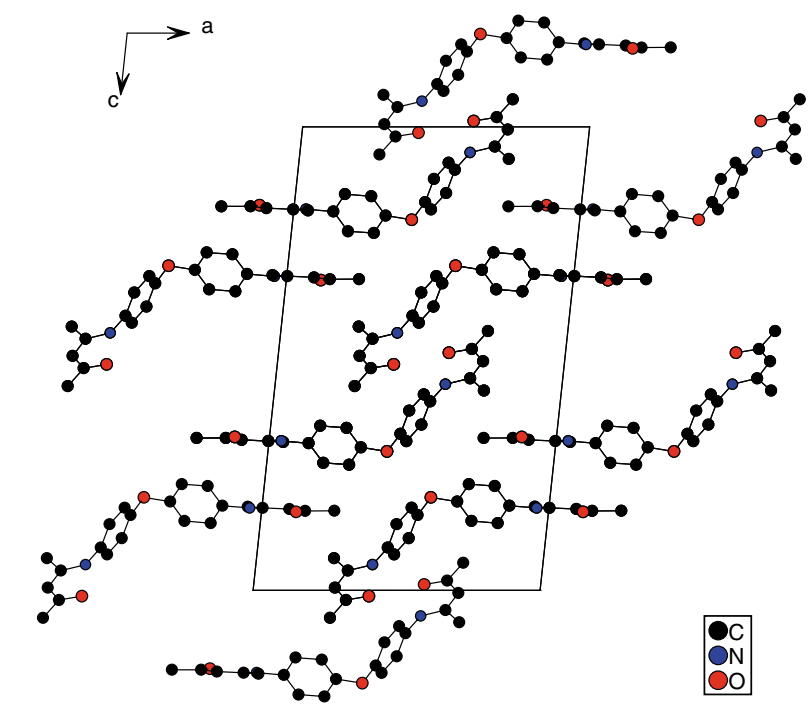

Fig. 3. Packing of the molecules along the $b$-axis.

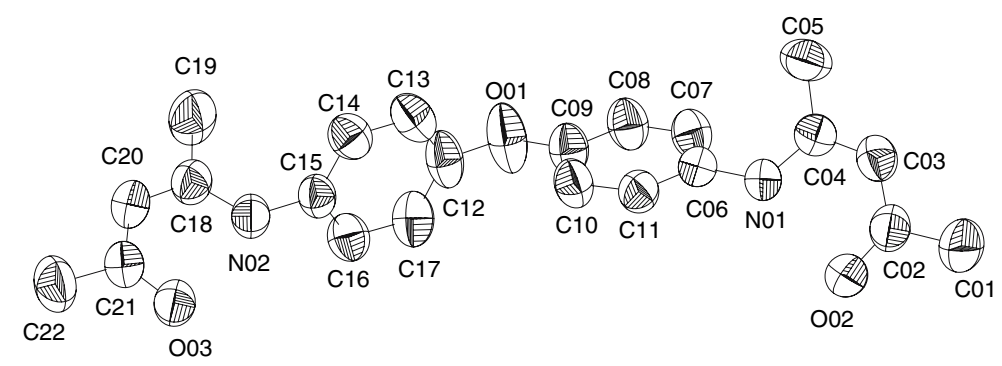

Fig. 2. ORTEP drawing ( $50 \%$ probability ellipsoïds) of the ligand (non hydrogen atoms) with numbering scheme. 


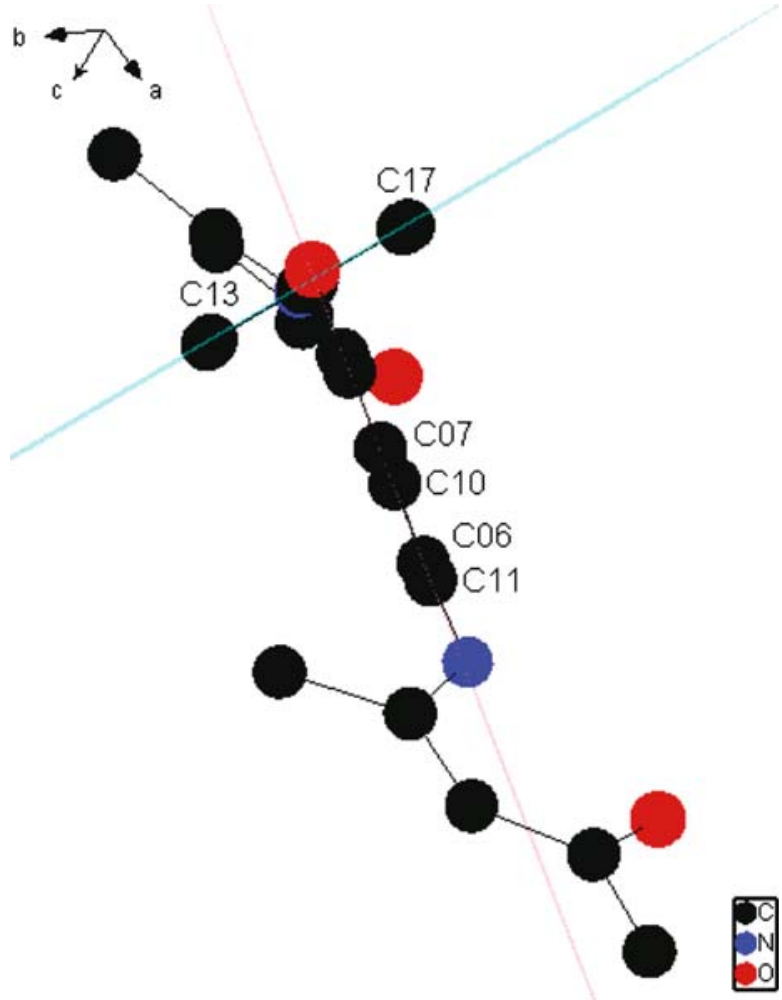

Fig. 4. View of the $80.8(1)^{\circ}$ angle between the planes of the two aromatic rings.

of the band is similar, indicating the absence of hydrogen bonding and this is in favour of keto-imine form I.

In the solid state, the ligand and the complexes appear to be, mainly in keto-imine tautomer. In $\mathrm{Co}^{\mathrm{II}}$, $\mathrm{Ni}^{\mathrm{II}}$ and $\mathrm{Cd}^{\mathrm{II}}$ complexes, the chelation occurs through $\mathrm{O}$ (keto) and $\mathrm{N}$ (imino) atoms because the keto stretching vibration band is shifted to higher wavenumbers when passing from the ligand to the complexes. Finally, the copper(II) complex is a mononuclear bid- entate species, acting through $\mathrm{N}$ (imino) atom because the carbonyl stretching vibration is not modified.

\section{Electronic spectra}

In the UV-visible region, the ligand absorbs mainly at $332 \mathrm{~nm}$ (Table 5), with three weak absorption bands at 258,248 and $235 \mathrm{~nm}$.

In the case of the cobalt(II) compound, two weak bands from $\mathrm{d}-\mathrm{d}$ transitions are observed at 600 and $670 \mathrm{~nm}$, corresponding to a tetrahedral environment around $\mathrm{Co}^{2+}$ ion $[28,29]$. The $\mathrm{Ni}^{\mathrm{II}}$ complex exhibits mainly the absorption bands of the ligand which are slightly shifted. In addition, a very weak and large absorption is located between 550 and $800 \mathrm{~nm}$.

The spectra of the copper(II) complex shows an intense and sharp band at $260 \mathrm{~nm}$ with a shoulder at $258 \mathrm{~nm}$ and a non gaussian broad one centred at $312 \mathrm{~nm}$. The band at $260 \mathrm{~nm}$ is attributed to $\mathrm{Cu}^{2+}$ ion (charge transfer band) [30]. Without any possible $\mathrm{d}-\mathrm{d}$ transitions, the spectrum of the $\mathrm{Cd}^{\mathrm{II}}$ complex presents the same bands (330, 255 and $248 \mathrm{~nm}$ ) than the ligand.

\section{${ }^{1} H$-n.m.r. spectra}

${ }^{1} \mathrm{H}$-n.m.r. spectra of the ligand in DMSO-D ${ }_{6}$, show a singulet (12 protons) at 2.0 p.p.m. for the protons of the four methyl groups. The aromatic protons appeared as two doublets located at 7.0 and 7.2 p.p.m. while the singulet at 12.4 p.p.m. is typical of a $\mathrm{NH}$ proton (enamine tautomer). In addition the signal at 5.2 p.p.m. was attributed to $\mathrm{CH}=\mathrm{C}$ proton $[20,26$, 27]. In the spectra, there is no signal corresponding to an hydroxyle proton (enol tautomer).

In the case of the $\mathrm{Cd}^{\mathrm{II}}$ complex, very few changes are observed and the signal at 12.4 p.p.m is assigned to the $\mathrm{NH}$ enamine tautomer proton. In addition the aromatic protons signal is split into two quadruplets at 6.6 and 7.2 p.p.m. As the $\mathrm{Cd}^{\mathrm{II}}$ ion is bounded, a steric

Table 5. Main spectroscopic data

\begin{tabular}{|c|c|c|c|c|c|c|c|c|}
\hline Compound & $\begin{array}{l}\text { Infrared } \\
v(\mathrm{~N}-\mathrm{H})\end{array}$ & $\begin{array}{l}\left.\mathrm{n}^{-1}\right)^{\mathrm{a}} \\
v(\mathrm{O}-\mathrm{H})\end{array}$ & $v(\mathrm{C}=\mathrm{O})$ & $v(\mathrm{C}=\mathrm{N})$ & $v(\mathrm{COC})$ & Arom. ring & $\begin{array}{l}\text { U.v.-vis } \\
\lambda(\mathrm{nm})\end{array}$ & $\begin{array}{l}\text { (DMF solution) } \\
{\left[\varepsilon\left(1 \mathrm{~mol}^{-1} \mathrm{~cm}^{-1}\right)\right]}\end{array}$ \\
\hline $\mathrm{H}_{2} \mathrm{~L}$ & 3450 & - & 1610 & 1571 & 1247 & $\begin{array}{l}1275 \\
1035 \\
860\end{array}$ & 332 & [630] \\
\hline$\left[\left(\mathrm{CoCl}_{2}\right)_{2}\left(\mathrm{H}_{2} \mathrm{~L}\right)\right]$ & 3433 & - & 1626 & 1575 & 1251 & $\begin{array}{l}1280 \mathrm{sh} \\
1085 \mathrm{sh} \\
875\end{array}$ & 310 & {$[550]$} \\
\hline$\left[\left(\mathrm{NiCl}_{2}\right)_{2}\left(\mathrm{H}_{2} \mathrm{~L}\right)\right] \cdot 2 \mathrm{H}_{2} \mathrm{O}$ & & $3407 b$ & 1619 & 1565 & 1239 & $\begin{array}{l}\text { 1277sh } \\
1086 \\
830\end{array}$ & 328 & {$[19,220]$} \\
\hline$\left[\mathrm{CuCl}_{2}\left(\mathrm{H}_{2} \mathrm{~L}\right)\right]$ & 3420 & - & $1606 \mathrm{sh}$ & 1582 & 1247 & $\begin{array}{l}1282 \\
- \\
833\end{array}$ & 312 & [1220] \\
\hline$[\mathrm{CdL}] \cdot \mathrm{CdCl}_{2}$ & 3471 & - & $1625 \mathrm{sh}$ & 1556 & 1245 & $\begin{array}{l}1268 \\
- \\
875\end{array}$ & 330 & {$[13,330]$} \\
\hline
\end{tabular}

${ }^{\mathrm{a}} \mathrm{sh}=$ shoulder; $\mathrm{b}=$ broad. 
hindrance occurs and the four protons in a cycle are therefore not totally equivalent.

\section{Thermal analysis}

The d.s.c. diagram of the ligand (powder) shows two endothermic peaks at 90 and $110{ }^{\circ} \mathrm{C}$ respectively. The second endotherm correspond to the melting of the molecule, while the first one results from polymorphism $[31,32]$. An endotherm occurs at $c a .330^{\circ} \mathrm{C}$ followed by several exothermic peaks due to the chemical decomposition of the molecule.

The cobalt(II) compound is very thermally stable, showing one thin endothermic peak only at $368^{\circ} \mathrm{C}$. On the opposite side, the d.s.c. diagram of the nickel(II) complex shows many peaks. The main ones occur in the $140-160{ }^{\circ} \mathrm{C}$ range and are due to the lost of water molecules.

The copper(II) complex presents an exothermic peak $\left(142{ }^{\circ} \mathrm{C}\right)$ immediately followed by an endotherm at

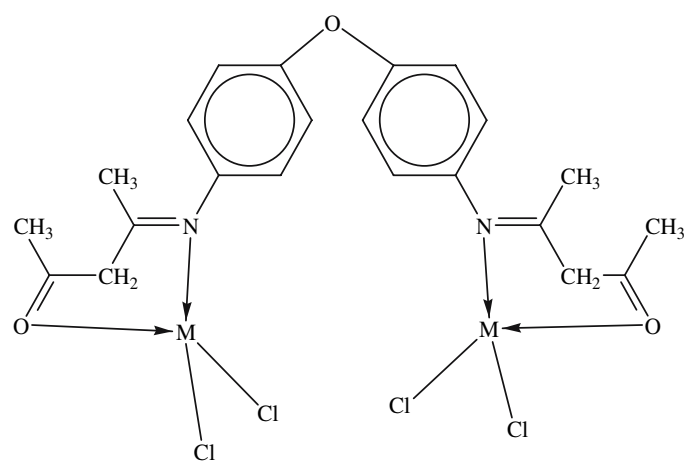

$\mathrm{M}=\mathrm{Co}$ or $\mathrm{Ni}$ (with $2 \mathrm{H}_{2} \mathrm{O}$ )
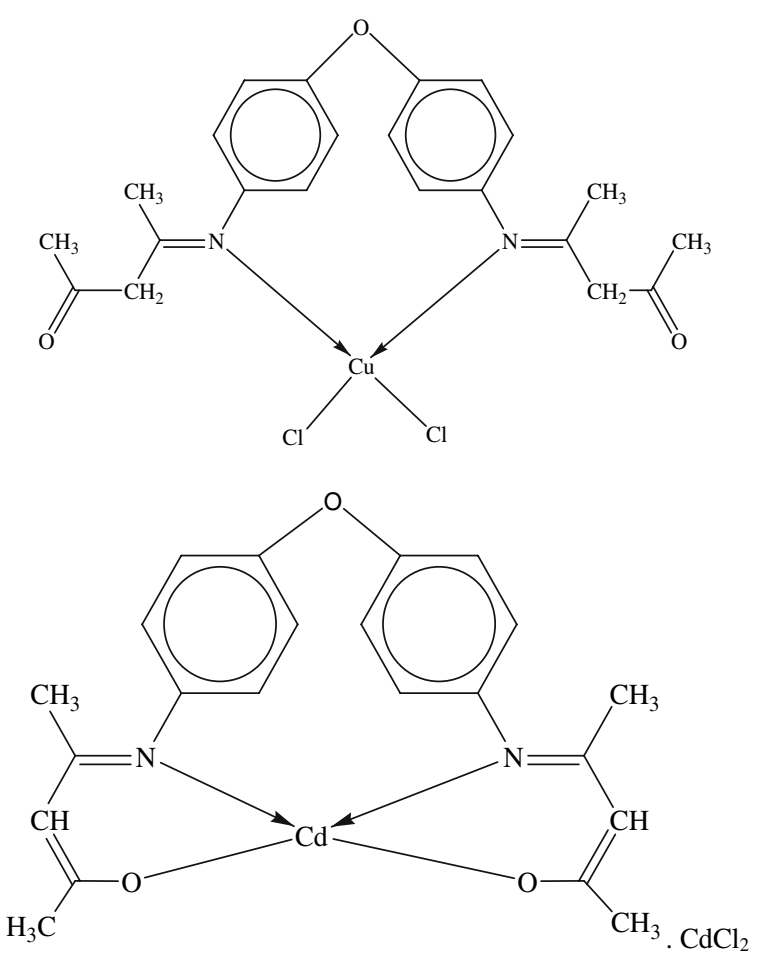

Fig. 5. Proposed structures for the complexes. $147^{\circ} \mathrm{C}$; finally the decomposition of this species produces many weak endothermic peaks between 300 and $380^{\circ} \mathrm{C}$. At last, the $\mathrm{Cd}^{\mathrm{II}}$ complex is also very stable as its d.s.c. diagram shows a very weak endotherm at $190{ }^{\circ} \mathrm{C}$ followed with a well-resolved endotherm at $395^{\circ} \mathrm{C}$.

\section{Proposed structures for the complexes}

The proposed structures are given in Figure 5. The ligand di[4-(phenylimino)pentan-2-one] ether is a potent pentadentate ligand but this Schiff base acts as a tetradentate $\mathrm{N}_{2} \mathrm{O}_{2}$ ligand via the keto-imine tautomer, showing an $E$ configuration. This geometry remains unchanged after complexation.

The cobalt(II) and the nickel(II) compounds exhibit the same structure. These compounds are binuclear complexes and the metal cation is linked through $\mathrm{N}$ (imino) and $\mathrm{O}$ (keto) atoms. The cobalt compound presents a distorted tetrahedral geometry while the nickel(II) complex exhibits a typical square planar surrounding [33]. In addition, two water molecules appear in the case of the nickel complex (as indicated by infrared spectroscopy and thermal analysis).

As shown in the infrared section, the copper(II) complex is a mononuclear species and the cupric ion is bounded through $\mathrm{N}$ (imino) atoms giving a quite square planar geometry. In fact, regular tetrahedral complexes of copper(II) are uncommon. There is a flattening of the tetrahedron as a consequence of Jahn-Teller effect. A small absorption in the u.v.-vis spectrum (not reported in Table 5) around $730 \mathrm{~nm}$ is typical of square planar $\mathrm{Cu}^{\mathrm{II}}$ complexes [33].

In the solid state, the cadmium(II) complex is built around one $\mathrm{Cd}^{2+}$ ion, in a tetrahedral geometry, coordinating through $\mathrm{N}$ and $\mathrm{O}$ atoms. The ligand is ionised as a dianion with a delocalisation of the $\pi$ electrons along the system. Finally, a $\mathrm{CdCl}_{2}$ is intercalated inside the complex species (Figure 6) [34].

\section{Electrochemical behaviour}

Some representative voltammograms are shown in Figure 6 and the main electrochemical results are given in Table 6.

In the $-1.80-0.71 \mathrm{~V}$ range, the ligand (Figure 6a) shows an irreversible anodic peak at $+1.33 \mathrm{~V}$ and a quasi reversible cathodic peak, located at $-0.42 \mathrm{~V}$ due to the reduction of the oxidised species of the ligand (oxidation of the azomethine moiety) obtained at $+1.33 \mathrm{~V}$ [22]. During reduction sweep, the cyclic voltamogram shows only one cathodic peak at $-1.03 \mathrm{~V}$ resulting from the reduction of the imino group [35].

When the speed sweep is varying (i.e. 500, 300, 200, 100,25 and $10 \mathrm{mV} \mathrm{s}^{-1}$ respectively), the curve $i_{\mathrm{pa}}$ (at $1.32 \mathrm{~V}$ ) as a function of speed square root is a straight line (not shown) and the curve $E_{\mathrm{pa}}=\mathrm{f}(\log \mathrm{v})$ is a curve line. These results show that this reduction peak corresponds to a diffusion controlled quasi-reversible system [34]. 
Table 6. Voltammetric results at $25^{\circ} \mathrm{C}$ in DMF, ionic strength $0.1 \mathrm{~mol}^{-1}\left(\mathrm{Bu}_{4} \mathrm{NPF}_{6}\right)$, results in $\mathrm{V}$ vs $\mathrm{SCE}$, sweep speed: $100 \mathrm{mV} \mathrm{s}{ }^{-1}, E_{\mathrm{pa}}$ : anodic; $E_{\mathrm{pc}}$ : cathodic

\begin{tabular}{|c|c|c|c|c|c|c|c|}
\hline Compound & $E_{\mathrm{pa} 1}$ & $E_{\mathrm{pa} 2}$ & $E_{\mathrm{pa} 3}$ & $E_{\mathrm{pa} 4}$ & $E_{\mathrm{pc} 1}$ & $E_{\mathrm{pc} 2}$ & $E_{\mathrm{pc} 3}$ \\
\hline $\mathrm{H}_{2} \mathrm{~L}$ & -0.28 & & & 1.33 & -0.42 & -1.03 & \\
\hline$\left[\left(\mathrm{CoCl}_{2}\right)_{2}\left(\mathrm{H}_{2} \mathrm{~L}\right)\right]$ & -0.18 & & 0.78 & 1.33 & & & -1.68 \\
\hline$\left[\left(\mathrm{NiCl}_{2}\right)_{2}\left(\mathrm{H}_{2} \mathrm{~L}\right)\right] \cdot 2 \mathrm{H}_{2} \mathrm{O}$ & -0.09 & & & 1.28 & & -1.30 & -1.69 \\
\hline$\left[\mathrm{CuCl}_{2}\left(\mathrm{H}_{2} \mathrm{~L}\right)\right]$ & -0.29 & 0.05 & 0.54 & 1.30 & 0.22 & -1.45 & -1.67 \\
\hline$[\mathrm{CdL}] \cdot \mathrm{CdCl}_{2}$ & & & & 1.18 & & -1.02 & -1.56 \\
\hline
\end{tabular}

a
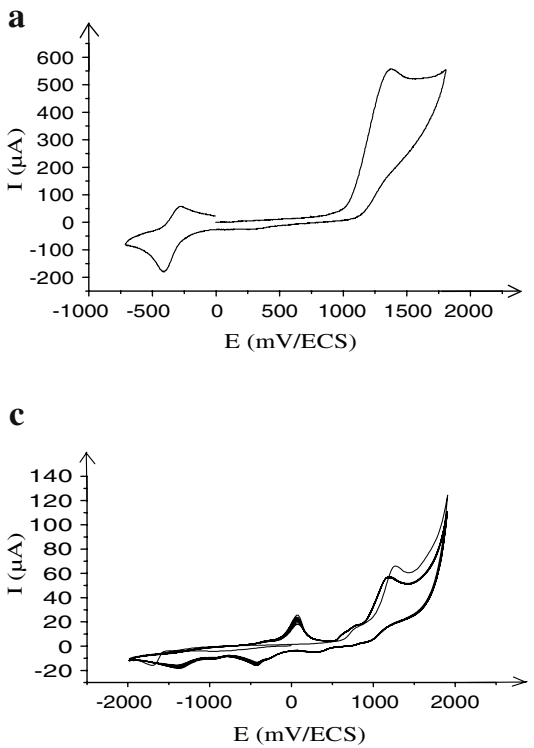

e

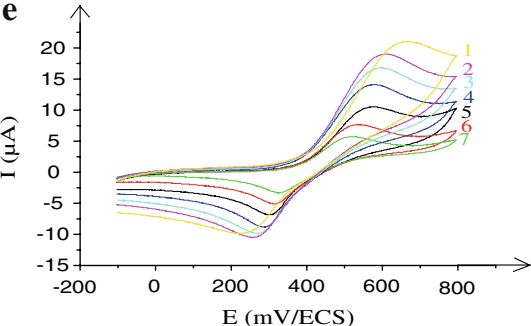

b
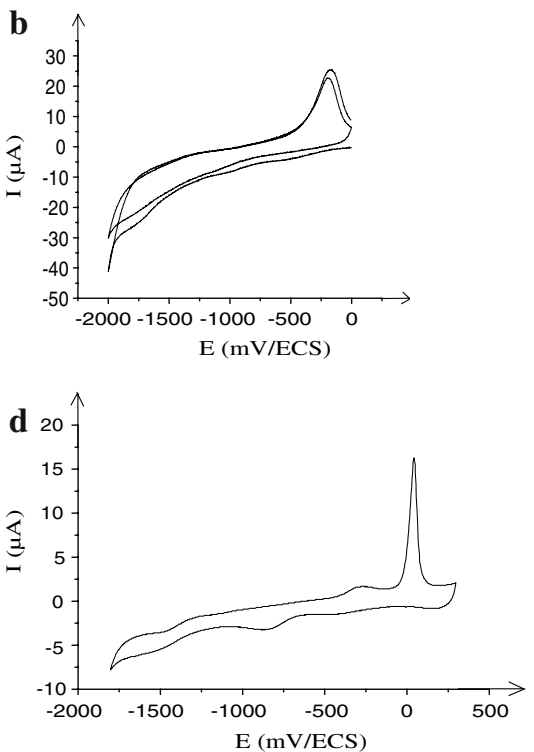

Fig. 6. Representative cyclic voltammograms in $\operatorname{DMF}\left(25^{\circ} \mathrm{C}\right.$, ionic strength: $0.1 \mathrm{~mol} \mathrm{l}^{-1}, \mathrm{Bu}_{4} \mathrm{NPF}_{6}, i$ in $\left.\mu \mathrm{A}, \mathrm{v}=100 \mathrm{mVs}^{-1}\right)$. a: ligand $(-1.80$ to $+1.80 \mathrm{~V})$; b: $\mathrm{Co}(\mathrm{II})$ complex $(-1.80$ to $1.80 \mathrm{~V})$, c: Ni(II) complex $(-2.00$ to $0.40 \mathrm{~V})$, d: $\mathrm{Cu}(\mathrm{II})$ complex $(-1.80$ to $0.30 \mathrm{~V})$; e: $\mathrm{Cu}(\mathrm{II})$ complex, variable speed $(0.80$ to $-.010 \mathrm{~V})$.

The electrochemical behaviour of the complexes in the whole range studied showed similar responses that could be considered as the sum of the individual response of the metal centre and of the ligand. On the cathodic side, the cyclic voltammogram of the cobalt(II) complex (Figure 6b) shows a cathodic peak at $-1.68 \mathrm{~V}$ and an reoxidation peak at $-0.18 \mathrm{~V}$. The cathodic peak at $-1.68 \mathrm{~V}$ corresponds the reduction of complexed $\mathrm{Co}^{\mathrm{II}}$ into $\mathrm{Co}^{0}$ [36]. Finally, $\mathrm{Co}^{0}$ is oxidised to give back coordinated $\mathrm{Co}^{\mathrm{II}}$ (anodic peak at $-0.18 \mathrm{~V}$ ), because this peak disappears when the sweep is lilted to the 1.80 to $-1.00 \mathrm{~V}$ range. Similar values were observed in various cobalt(II) complexes in the same solvent. When performing successive sweeps, the intensity of the peak at $-1.68 \mathrm{~V}$ diminished and in the mean time metallic cobalt was formed.
The nickel(II) compound, in addition to the ligand peaks, undergoes a reduction process located at $-1.69 \mathrm{~V}$ (Figure 6c) corresponding to the reduction of $\mathrm{Ni}^{\mathrm{II}}$ into $\mathrm{Ni}^{0}$ and the reoxidation of $\mathrm{Ni}^{0}$ occurs at $-0.92 \mathrm{~V}$. These values agree with those previously described for nickel complexes in the same solvent [37, 38] or with symmetrical Schiff bases [39].

In the cyclic voltammogram of the complex with copper (Figure 6d and 6e), there are three cathodic peaks $(-0.84,-1.45$ and $0.22 \mathrm{~V})$ and four anodic peaks $(-0.29,0.05,0.54$ and $1.30 \mathrm{~V})$. The oxidation at $+0.54 \mathrm{~V}$ is due to the complexed $\mathrm{Cu}^{\mathrm{II}}$ oxidised into $\mathrm{Cu}^{\text {III }}$ and the peak at $+0.22 \mathrm{~V}$ corresponds to the reduction of the preceding $\mathrm{Cu}^{\mathrm{III}}$ giving $\mathrm{Cu}^{\mathrm{II}}[40]$.

Finally, the $\mathrm{Cd}^{\mathrm{II}}$ complex shows a similar behaviour with another symmetric Schiff base [20]. 
These results are in good agreement with the above proposed structures.

\section{Supplementary material}

Crystallographic data have been deposited with the CCDC (12 Union Road. Cambridge, CB2 IEZ, UK (fax: + 44-1223-336033; e-mail: deposit@ccdc.cam.ac. uk or at http://www.ccdc.cam.ac.uk), and are available on request quoting the deposition number CCDC 611567.

\section{References}

1. P. Pfeiffer, E. Breith, E. Lubbe and T. Tsumaki, Ann., 84 (1993).

2. H. Cheng, D. Chun-Ying, F. Chen-Jie and M. Qing-Jin, J. Chem. Soc. Dalton Trans., 2419, (2000).

3. U. Casellato, S. Tamburini, P. Tomasin and P.A. Vigato, Inorg. Chim. Acta, 357, 4191 (2004).

4. A. Mentes, M. Sarbay, B. Hazer and H. Arslan, Appl. Organometal. Chem., 19, 76 (2005).

5. A.T. Vallina and H. Stoeckli-Evans, Acta Cryst., C57, 489 (2001).

6. A. Combes and C. Combes, Compt. Rend., 108, 1252 (1889).

7. G.T. Morgan and J.D.Main-Smith, (a) J. Chem. Soc., 2030 (1925); (b) ibid., 912 (1926).

8. G. Schwarzenbach and K. Lutz, Helv. Chim. Acta, 23, 1139 (1940).

9. P.J. Mc Carthy, R.J. Hovey, K. Ueno and A.E. Martell, J. Am Chem. Soc., 77, 5820 (1955).

10. M.J. Carter, D.P. Rillema and F. Basolo, J. Am. Chem. Soc., 96, 392 (1974).

11. N.S. Enikolopyan, K.A. Bogdanova and K.A. Askarov, Russ. Chem. Rev., 52, 13 (1983)

12. W.H. Leung and C.M. Che, Inorg. Chem., 28, 4619 (1989).

13. P.K. Battacharya, Proc. Indian Acad. Sci. (Chem. Sci.), 102, 247 (1990).

14. A.M. El-Hendawy, A.H. Alkubaisi, A.E.K. El-Kourashy and M.N. Shanab, Polyhedron, 12, 2343 (1993).

15. Y.P. Cai, C.Y. Su, A.W. Xu, B.S. Kang, Y.X. Tong, H.Q. Liu and S. Jie, Polyhedron, 20, 657 (2001).

16. R.H. Nishwander, A.K.S. Clair, S.R. Edmondson and L.T. Taylor, Inorg. Chem., 14, 478 (1975).

17. M. Tsuchimoto, T. Ishii, T. Imaoka and K. Yamamoto, Bull. Chem. Soc. Jpn., 77, 1849 (2004).

18. R. Ando, S. Mori, M. Hayashi, T. Yagyu and M. Maeda, Inorg. Chim. Acta, 357, 1177 (2004).
19. S. Issaadi, D. Haffar, T. Douadi, S. Chafaa, D. Séraphin, M.A. Khan and G. Bouet, Synt. React. Inorg. Met-Org. Nano-Met. Chem., 35, 875 (2005).

20. A. Ghames, T. Douadi, D. Haffar, S. Chafaa, M. Allain, M.A. Khan and G.M. Bouet, Polyhedron, 25, 3209 (2006).

21. K.H. Reddy, M.R. Reddy and K.M. Raju, Polyhedron, 16, 2673 (1997).

22. A.A. Isse, A. Gennaro and E. Vianello, Electrochim. Acta, 42 , 2065 (1997).

23. G.M. Sheldrick, SHELX97 - Programs for Crystal Structure Analysis (Release 97-2). University of Göttingen, Germany, 1998.

24. K. Ueno and A.E. Martell, J. Phys. Chem., 59, 998 (1955).

25. L.C. Nathan and C.A. Traina, Polyhedron, 22, 3213 (2003).

26. G.O. Dudek and R.H. Holm, J. Am. Chem. Soc., 83, 2099 (1961).

27. P.J. Mc Carthy and A.E. Martell, Inorg.Chem., 6, 781 (1967).

28. S. Lechat, M.A. Khan, G. Bouet and F. Vierling, Inorg. Chim. Acta, 211, 33 (1993).

29. A.B.P. Lever, Inorganic Electronic Spectroscopy, 1st edn, Elsevier, Amsterdam, 1968.

30. E. Bentouhami, M.A. Khan, J. Meulemeestre and F. Vierling, Polyhedron, 11, 2179 (1992).

31. A.L. Grzesiak, M. Lang, K. Kim and A.J. Matzger, J. Pharm. Sciences, 92, 2260 (2003).

32. F. Jian, H. Wang and H. Xiao, Struct. Chem., 15, 227 (2004).

33. A.B.P. Lever, Inorganic Electronic Spectroscopy, 2nd edn. Elsevier, Amsterdam, 1984.

34. D. Haffar, T. Douadi, S. Chafaa, M.A. Khan and G. Bouet, Transition Met. Chem., 29, 245 (2004).

35. P. Gili, M.G. Martin Reyes, P. Martin Zarza, I.L.F. Machado, M.F.C. Guedes da Silva, M.A.N.D.A. Lemos and A.J.L. Pombeiro, Inorg. Chim. Acta, 244, 25 (1996).

36. E.K. Beloglazkina, A.G. Majouga, R.B. Romashkina, A.A. Moiseeva and N.V. Zyk, Polyhedron, 26, 797 (2007).

37. W. Mazurek, A.M. Bond, M.J. O'Connor and A.G. Wedd, Inorg. Chem., 25, 906 (1986).

38. R.L. Lintveld, G. Ranger and L.S. Kramer, Inorg. Chem., 25, 2365 (1986).

39. F. Azevedo, C. Freire and B. de Castro, Polyhedron, 21, 1695 (2002).

40. M. Aguilar-Martínez, R. Saloma-Aguilar, N. Macías-Ruvalcaba, R. Cetina-Rosado, A. Navarrete-Vázquez, V. Gómez-Vidales, A. Zentella-Dehesa, R.A. Toscano, S. Hernández-Ortega, and J.M. Fernández-G., J. Chem. Soc., Dalton Trans. 2346 (2001).

TMCH 6789 